\title{
Giving wings to logic: Mary Everest Boole's propagation and fulfilment of a legacy
}

\author{
K. G. VALENTE*
}

\begin{abstract}
In his influential Laws of Thought (1854), the mathematician George Boole presented a formulation of logic using algebraic expressions and manipulations. His widow, Mary Everest Boole, undertook an ambitious project of disseminating his ideas by introducing lay audiences to the law of pulsation, a prescription for correct reasoning that incorporates two of his fundamental insights. Contemporary scholarship presents a fragmented picture of Mary Boole, regarding her largely as a source of information on the religio-psychological impetus for her husband's contributions to logic, among other matters. Some studies rightly acknowledge that her better-known commentary on educational reform relates to a promotion of the Laws of Thought, yet these typically fail to expand on how she articulated such relationships for readers. This paper provides a more complete understanding of her efforts by examining texts on various subjects motivated by a dedication to propagating as much as fulfilling the intellectual legacy she associated with her husband. In doing so it considers her interventions - like those undertaken by other Victorian women who sought to cultivate scientific enterprises - within a contextual framework broad enough to include strategic responses to cultural realities and possibilities.
\end{abstract}

The influential member and sometime head of the respected Department of Education at the University of Chicago, Ralph Tyler, employed language imbued with historical significance when he declared his admiration for Mary Everest Boole. According to his mid-twentieth-century testimonial, 'her conceptions of child psychology and of learning, as well as her understanding of the psychological nature of mathematics and science, make her a pioneer in this generation as in the last' ${ }^{1}$ This is high praise, to be sure. But it also strongly suggests that her reputation, while deserving of note, was at that time undervalued. If that were truly Tyler's concern then, it continues now. More than fifty years after this assessment, it is disheartening to find that this remarkably dedicated and formidably gifted woman remains an obscure figure in the modern history of science. Many will associate her with her husband, George Boole, the innovative mathematician and logician, yet few will be in a position to fully appreciate the scope

\footnotetext{
" Department of Mathematics, Colgate University, Hamilton, NY 13346, USA. Email: kvalente@mail. colgate.edu.

Part of this work was presented at the Three Societies Conference of the BSHS, HSS and CSHPS dedicated to Connecting Disciplines, Keble College, Oxford, 4-6 July 2008. I wish to thank Kevin Lambert for sharing his enthusiasm for Mary Everest Boole and this project, as well as for reading and commenting on an earlier draft of this essay. The anonymous reviewers also provided many helpful suggestions, and I am equally grateful for their contributions.

1 R. W. Tyler, quoted in E. M. Cobham, Mary Everest Boole: A Memoir with Some Letters, Ashington, 1951, 11.
} 
of the mission she undertook in her half-century of widowhood. Her work may well have found its initial and continued inspiration in a desire to commemorate and contextualize George's genius as only she could. However, as Tyler's tribute clearly indicates, Mary eventually transcended her role as a biographer by undertaking forays into a variety of intellectual and professional domains. ${ }^{2}$

Contemporary scholarship has primarily recognized Mary's accomplishments by providing a sense of her contributions to educational discourse and practice in the early twentieth century. Some references, such as the one found in Geoffrey Howson's survey of mathematics education in Britain, simply note her efforts in passing. Others, such as Mary Creese's entry for the Dictionary of National Biography, justly give these greater prominence. ${ }^{3}$ Readers interested in more focused accounts of her opinions, innovations and prescriptions in the area of mathematical pedagogy can consult recent studies by Shelley Innes and Karen Michalowicz. ${ }^{4}$ While such scholarship certainly helps to rekindle an admiration for her progressive and creative efforts, little of this research speaks to an essential concern. This is the task of placing her educational projects in the broader context of Victorian women whose writing engaged scientific subject matter. For their part, biographers and historians of science have tended to cast Mary in the reflected light of her husband. She therefore remains a vague, incomplete and sometimes malevolent figure in their accounts. For example, Michalowicz and Ivor Grattan-Guinness correctly acknowledge that her engagement with educational reform was part of a mission to promote the ideas of her husband George. Nevertheless, their observations leave unresolved questions about the range of intellectual attitudes she adopted as well as strategies she employed in prosecuting this charge. ${ }^{5}$ At the same time, Desmond MacHale casts doubts on both the quality and state of her mind, which ultimately suggest that her decision to champion George had the potential to do his reputation more harm than good. However, MacHale does so largely by presenting provocative extracts from her works selected for their disparate and vague references. ${ }^{\mathbf{6}}$ It is certainly difficult to overlook the fact that, throughout her prolific career, Mary

2 Forsaking formality for expedience, I have chosen to employ the given names of the two central characters of this study.

3 M. R. S. Creese, 'Boole, Mary (1832-1916)', DNB, Oxford, 2004, available at http://0-www. oxforddnb.com.library.colgate.edu:80/view/article/38817, accessed 3 March 2008; G. Howson, Mathematical Education in England, Cambridge, 1982, 170.

4 S. Innes, 'Mary Boole and curve stitching: a look into heaven', Endeavour (2004), 28, 36-8; K. D. A. Michalowicz, 'Mary Everest Boole (1832-1916): an erstwhile pedagogist for contemporary times', in Vita Mathematica: Historical Research and Integration with Teaching (ed. R. Calinger), Washington, DC, 1996, 291-9.

5 Michalowicz, op. cit. (4), 295; I. Grattan-Guinness, Mathematical Roots: Logics, Set Theories and the Foundations of Mathematics from Cantor through Russell to Gödel, Princeton, NJ, 2000, 54.

6 It is also worth noting that MacHale asserts that Mary had 'little knowledge of mathematics and little more than superficial understanding of her husband's work'. D. MacHale, George Boole: His Life and Work, Dublin, 1985, 256-9, 258. Grattan-Guinness, however, agrees with others in maintaining that she was 'a woman of considerable intellect' who had a 'good understanding of his ideas'. I. Grattan-Guinness, 'Psychology in the foundations of logic and mathematics: the case of Boole, Cantor and Brouwer', History and Philosophy of Logic (1982), 3, 33-53, 34 n. 1; idem, op. cit. (5), 54. 
was prone to unusual flights of fancy, but it is equally problematic to disregard the consistently identifiable themes that infuse her writing.

In addition to her commentary on education, Mary has received considerable attention for her chronicles of her husband's private life and personal motivations. Despite his concerns about the more eccentric extremes of her treatment of George's legacy, MacHale obviously finds many of her recollections reliable. Similarly, Luis Laita explores Boolean algebra's extra-logical influences by analysing various texts produced by George during his lifetime in relation to Mary's later reminiscences. Laita makes a compelling case for acknowledging metaphysical concerns, believing that her accounts provide trustworthy evidence of the many strands of his thinking at the time. ${ }^{7}$ Notwithstanding their extensive research and obvious respect for the biographical merits of Mary's writing, MacHale and Laita both fall well short of providing insights into a significant area of investigation. Accepting that she found inspiration in her intimate and privileged knowledge of her husband's convictions, one might justifiably query the extent to which she used the role of chronicler as a means of initiating original acts of (re)interpretation or intellectual synthesis. As Kathryn Neeley's study of Mary Somerville reminds us, it would be short-sighted to maintain the criterion that 'making discoveries is the only way to earn a place in the history of science'. To do so fails to appreciate the 'cultivation [of science] as a distinct form of activity'. We can also profitably follow the example of scholars such as Mary Orr by paying particular attention to women who engaged in such activities by virtue of familial relationships. ${ }^{8}$

This essay seeks to render a more complete portrayal of Mary and the project she undertook as George's widow in promoting his ideas. Kevin Lambert's recent essay detailing Mary's involvement in commemorating George through the medium of stained glass provides a thought-provoking stimulus for renewed research. ${ }^{9}$ My primary motivation, however, lies in filling several gaps in the scholarly literature by examining her writing on a variety of subjects including education, psychology, gender roles and women's suffrage, the experiential aspects of mathematical knowledge, the antivivisection movement and the ongoing professionalization of science. This is carried out in relation to a single theme of which she articulated and cultivated an appreciation in much of her commentary: the law of pulsation. In doing so, I also pay particular attention to the ways in which she positioned herself in various discourses, communicated her agency or established her credibility, and tailored her messages for specific audiences.

With few exceptions, Mary's ambition to disseminate the law of pulsation served as a point of entry for her many contributions to discussions dedicated to the

7 L. M. Laita, 'Boolean algebra and its extra-logic sources: the testimony of Mary Everest Boole', History and Philosophy of Logic (1980), 1, 37-60.

8 K. Neeley, Mary Somerville: Science, Illumination, and the Female Mind, Cambridge, 2001, 16. Mary Orr considers the contributions of such women in 'Pursuing proper protocol: Sarah Bowdich's purview of the sciences of exploration', Victorian Studies (2007), 49, 277-85. Women's engagements with the popularization of science are also thoroughly explored in B. T. Gates and A. B. Shteir (eds.), Natural Eloquence: Women Reinscribe Science, Madison, 1997.

9 K. Lambert, 'Victorian stained glass as memorial: an image of George Boole', in Visions of the Industrial Age, 1830-1914: Modernity and the Anxiety of Representation in Europe (ed. M. Kang and A. WoodsonBoulton), Aldershot, 2008, 205-26. 
aforementioned topics; put another way, it legitimized her engagements. The authority she claimed in these undoubtedly rested on a portrayal of herself as a confidant to George's genius. However, she also drew heavily on her own experiences as a student of mathematics, teacher and parent when writing on education. In addressing suffrage, Mary deftly amplified her agency by melding her roles as messenger of the law of pulsation and model for fulfilling the obligations it implied for women. Speaking to scientists in terms of their intellectual responsibilities provides another illustration of how she sought to establish credibility, as such was meant to ensure that her critique of vivisection could not be easily dismissed as moral sermonizing. Perhaps the most impressive aspect of her project is the variety of commentaries she crafted around the law of pulsation. Mary's thoughts on the nature of mathematical knowledge in relation to this law provide but one example of her attempts to address particular audiences and concerns.

In constructing this survey it must be acknowledged that the selection of material from her extensive catalogue of essays, lectures and books allows much to pass without critical comment. Although others may well find reasons for drawing greater attention to their more esoteric, mystical or fanciful content, my approach is restricted to the treatment of her texts as sources of evidence for identifying organizing ideas and impulses. Ultimately this is an act of redress, one that offers a case for the re-examination of Mary as both an effective propagator of her husband's legacy and, in fulfilment of it, an original thinker in her own right.

\section{Complementary spirits seeking harmony}

Mary Everest was born in England, but spent a considerable portion of her childhood in France. ${ }^{10}$ Her father, the Reverend Thomas Everest, left his Gloucestershire parish owing to poor health and settled with his family in Paris when Mary was five. There the entire family came under the influence of Samuel Hahnemann, the German physician who originated homeopathic practices. The family followed a strict regime influenced by the hygienic philosophy he espoused. While her chronicles of some of the more formidable Hahnemannian directives observed in her youth, including bathing in icecold water and taking snowy, wintertime walks by lantern-light before breakfast, testify to a matter-of-fact reserve, Mary effusively recounted memories of her experiences with private tuition in a short memoir entitled 'A child's idyll'. She was particularly fond of her mathematics teacher, Monsieur Déplace, and his non-pedantic approach to lessons, through which she developed a lifelong interest in mathematics and began to conceive of the mind's ability to establish an unmediated connection with its concepts. ${ }^{11}$ These childhood episodes made a lasting impression on her, and hygienic and educational concerns occupied much of her thoughts later in life.

Other recurrent themes and interests detailed in Mary's extensive collection of written works owe much to her father. By her accounts, Thomas Everest was an unconventional and controversial figure. She acknowledges that he was a 'learned

10 Biographical sketches of Mary's early life can be found in several secondary sources, including Cobham, op. cit. (1); Creese, op. cit. (3); Innes, op. cit. (4); MacHale, op. cit. (6).

11 Mary Everest Boole, Collected Works (ed. E. M. Cobham), 4 vols., London, 1931, iv, 1506-23. 
occultist in days when occultists were few ... [who] called attention to the dangerous [reaction] which must come if the clerical and medical professions persisted in ignoring the phenomena of Mesmerism, Trance, and Clairvoyance'. ${ }^{12}$ He further alarmed fellow clergymen by adopting a pastoral doctrine that envisioned his role as servant to the 'desires of his most serious and wise' parishioners rather than that of priest. According to Mary, her father was also particularly disdainful of attempts to convert Jews to Christianity, believing that Judaism deserved to be respected for its traditions and interpretations of sacred texts. ${ }^{13}$ The Reverend Everest's ecumenism, which embraced aspects of spiritualism as it legitimated an inclusive perspective on spirituality, had a profound effect on Mary, who developed a freethinking and inquisitive approach to religious topics.

George Boole may well have shared many of Mary's nonconformist inclinations, but, unlike her, he steadfastly refrained from espousing these publicly. ${ }^{14}$ Although he was baptized in the Church of England and seriously considered joining the clergy, he eventually identified himself as a dissenter. Shortly thereafter he began to question both the veracity of the Bible and the legitimacy of Trinitarian doctrines. At the same time, George was attracted to monism, largely in response to numerous conversations with a Jewish friend who taught Hebrew in his hometown of Lincoln. In particular, the Judaic tradition of referring to God as the great All encouraged him to consider the 'Infinite Unknown as Unity'. ${ }^{15}$ In later life, reading widely sated his eclectic religious appetite. The thinking of the French theologians Ernest Renan and Auguste Gratry as well as of the Anglican cleric Frederick Maurice and the British rabbi David Woolf Marks influenced him significantly. With interests that spanned a variety of beliefs and practices, it is unsurprising that George personally dedicated himself to religious impartiality, finding it impossible to accept any particular doctrine or condone idolatry of any kind.

Setting aside his clerical aspirations, George developed his interest in mathematics largely through his own initiative and personal contacts. He studied symbolic algebra with Edward Bromhead, president of the Lincoln Mechanics Institute and former member of the Cambridge Analytical Society. His first research paper was published in the Cambridge Mathematical Journal in 1841. D. F. Gregory, who then served as the journal's editor, provided both assistance and mentorship in this undertaking. At the time George was a respected teacher in Lincoln, his professional options being constrained by his refusal to sign the Thirty-Nine Articles. In 1849, however, he moved to Cork, where he took up his post as the first mathematics professor at the recently established Queen's College. Shortly thereafter George met Mary during a visit to her uncle John Ryall, then vice-president of the college. While their opinions on certain matters were markedly divergent, in many respects it must have seemed that each had found a complementary partner in the other. Mutual interests in spirituality and

12 Boole, op. cit. (11), i, 82.

13 Boole, op. cit. (11), iii, 950-5, 950.

14 George Boole's religious beliefs are thoroughly examined in MacHale, op. cit. (6), Chapter 14. As previously observed, his account draws heavily on Mary's published recollections.

15 Boole, op. cit. (11), iii, 953. 
mathematics figured prominently in their courtship as well as in their later life together. Indeed, their relationship evolved partly as a consequence of time they spent together devoted to Mary's private tuition, George proving particularly helpful to overcoming her various difficulties with differential calculus. ${ }^{16}$

Sometime before their marriage in 1855 George promised Mary that he would seek her assistance in his work. ${ }^{17}$ Despite her considerable intellect, Mary felt incapable of contributing to his mathematical research. It is therefore no surprise that it took some years for the two to discover a way through which George's promise might be kept. Regardless of the extent to which her self-perception as a mathematical practitioner was justifiable, Mary had good reason to expect that she would continue to benefit from her husband's mathematical instruction. ${ }^{18}$ For his part, George's ambition to involve Mary challenges the notion of separate spheres of influence by fostering an essential melding of personal strengths. This likely owed much to a theological position advocated by Frederick Maurice, whom George greatly admired. Specifically, Maurice held that men and women are wedded to each other in the same way as the complementary virtues of manly truth and womanly obedience were wholly integrated in Christ's humanity. ${ }^{19}$ Eventually a publisher's suggestion offered a resolution apparently amenable to both sets of expectations, which Mary modestly described:

As I had not sufficient knowledge to assist my husband in prosecuting mathematical researches, I would try to make use of my ignorance, by representing the uninstructed public, who waited for enlightenment till he should make himself intelligible. I was to be a sort of lay-figure ... on whom the new book should be tried, to judge of the effect. ${ }^{20}$

The new book was A Treatise on Differential Equations (1859), and this working relationship implies that Mary would have had to acquire a thorough grounding in the subject in order to be an effective, if unofficial, editor. As further evidence of her

16 Boole, op. cit. (11), iii, 930. This aspect of their lives together has been discussed elsewhere; see especially Laita, op. cit. (7), 39.

17 Boole, op. cit. (11), i, 28-9.

18 While the strategies she later pursued owed much to her personal circumstances and ingenuity, Mary negotiated cultural stereotypes and intellectual dilemmas then commonly confronted by women of ambition. A wealth of literature explores nineteenth-century representations of women in relation to creative agency and knowledge production, including D. David, Intellectual Women and Victorian Patriarchy: Harriet Martineau, Elizabeth Barrett Browning, George Eliot, London, 1987, 1-23; Neeley, op. cit. (8), Chapter 1; E. Richards, 'Darwinian science and women intellectuals', in Victorian Science in Context (ed. B. Lightman), Chicago, 1997, 119-42; A. Winter, 'A calculus of suffering: Ada Lovelace and the bodily constraints on women's knowledge in early Victorian England', in Science Incarnate: Historical Embodiments of Natural Knowledge (ed. C. Lawrence and S. Shapin), Chicago, 1998, 202-39, 206-11. Particular problems inherent with acquiring mathematical skills without access to formal education are considered in A. Warwick, Masters of Theory, Chicago, 2003, Chapter 1.

19 Maurice's theological position goes some way in explaining George and Mary's intellectual and working relationship during the years of their marriage. He once proclaimed, 'Truth is essentially the manly virtue', which in the person of Christ was 'wedded to Obedience, the characteristic of woman'. As an example of duality tending unity, Maurice maintained that 'Christ ... exhibits the perfect type of that nature which belongs to man and woman. Neither the woman is without the man, nor the man without the woman in Him.' Frederick Maurice, quoted in H. F. G. Swanston, Ideas of Order: Anglicans and the Renewal of Theological Method in the Middle Years of the Nineteenth Century, Assen, 1974, 105.

20 Boole, op. cit. (11), i, 28. 
dedication to their shared task, she attended his lectures (before her womanly presence was deemed an inappropriate distraction) and worked alongside his students in preparing examples for a future edition of Differential Equations. Some time later, their mathematical attention turned to the subject of finite differences. As Mary recalled, 'We had no text-book, we created one as we went on. ${ }^{21}$

Although she acknowledged no direct involvement with its development, Mary later proclaimed her greatest intellectual affinity for George's Investigation of the Laws of Thought: On Which Are Founded the Mathematical Theories of Logic and Probabilities (1854). Perhaps the most significant aspect of this influential work is its attempt to formalize logic in terms of symbolic-or algebraic-expressions and manipulations. ${ }^{22}$ This certainly owed much to the nineteenth-century view of algebra as a notational language abstracted from arithmetic that applied to solving numerical problems. However, his particular innovation accepted that consistent systems beyond those whose referents related to quantity might be productively recast algebraically. As his title suggests, he was preoccupied with the algebraization of laws he associated with correct reasoning. He foreshadowed his intentions in 'The claims of science', an address delivered at Queen's College in 1851, when he asserted 'the moral and the intellectual constitution of man [as] proper objects of scientific inquiry'. Indeed, he was convinced that 'there are ... rigorous, ... scientific laws of thought and reason' ${ }^{23}$

Central to the calculus of reasoning on which George sought to 'establish the science of Logic and construct its method' were the unity law and Boole's equation. ${ }^{24}$ The former law incorporates his novel assignment of unity to any universe of thought, as expressed by a relationship symbolizing the law of the excluded middle: $x+(\operatorname{not}-x)=1$. George applied his algebraic notation to mental acts that referred to both classes of objects and propositions. In the former context, + signifies the union of two mutually distinct classes within a particular universe of thought; that is, $x+y$ denotes the class of objects that belong either to the class $x$ or to the class $y$. For situations in which the class $x$ contained all members of the class $y$, he employed the notation $x-y$ to denote the class of objects that belong to $x$, but not to $y$. The unity law is therefore expressible as $x+(1-x)=1$. George also adopted the juxtaposition $x y$ to denote the class of all objects that are simultaneously members of the classes $x$ and $y$ as well as the numerical symbol 0 to signify the class containing no objects. With these, Boole's equation can be represented algebraically as $x(1-x)=0$, which, among other things, encodes the principle of contradiction; that is, no object can simultaneously satisfy and fail to satisfy a particular condition.

21 Boole, op. cit. (11), i, 29.

22 George first contemplated algebraizing logic in his Mathematical Analysis of Logic (1847), a work with which he later expressed some dissatisfaction. By his own admission, he felt Laws of Thought would secure his legacy; see MacHale, op. cit. (6), 127-8.

23 G. Boole, The Claims of Science, London, 1851, 15, 17.

24 G. Boole, An Investigation of the Laws of Thought, on which are Founded the Mathematical Theories of Logic and Probabilities, London, 1854, 1. One will find various names attached to these laws in the literature. For example, George sometimes preferred referring to the latter as the law of duality; ibid., 51. Those I have chosen were used most frequently by Mary and are therefore best suited to the themes explored herein. 
Despite the originality and significance of his research, Mary claimed that George 'cared for [logic] chiefly as a means of clearing the ground of doctrines imagined to be proved, by showing that the evidence on which they were supposed to rest had no tendency to prove them'. ${ }^{25}$ This appraisal, considered alongside religious references contained in the final chapter of Laws of Thought, is an indication that his motives at the time were not strictly constrained by disciplinary concerns. ${ }^{26}$ As a private man whose educational and professional history served to keep him at the margins of the mathematical mainstream, however, he was understandably reluctant to attract undue attention to himself by connecting his work with broader themes. Apparently his feelings changed over time, for he eventually began work on a manuscript intended for a popular readership that was to de-emphasize the mathematics of the Laws of Thought in favour of philosophical, psychological and religious discussions. ${ }^{27}$

Shortly before his sudden death George signalled to Mary some other shifts in attitude and suggested intellectual challenges that she might undertake on her own. ${ }^{28}$ His work on a more accessible sequel to the Laws of Thought was apparently hindered by a conceptual problem. According to Mary's recollection, he could not 'see his way' to approaching his subject matter in a suitable manner. ${ }^{29}$ The two had many conversations about this problem, intertwined as it was with his religious attitudes and beliefs, and how he might resolve his dilemma. These discussions were almost certainly the subject of George's admission to Augustus De Morgan, with whom he maintained a long correspondence, that 'there is absolutely no person in [Ireland] except my wife with whom I ever speak on subjects like [logic]' ${ }^{30}$ During one period of reflection Mary offered a biblical passage that to her mind provided a possible solution to some of her husband's difficulties, specifically those concerning the topic of inspiration. Mary's particular focus was the verse John 3:8: 'The wind bloweth where it listeth, and thou hearest the sound thereof, but canst not tell whence it cometh, and whither it goeth: so is every one that is born of the Spirit. ${ }^{31}$ However, she interpreted the wind described therein as the 'geometric figure of the dust-whirl'. ${ }^{32}$

The spiral behaviour of a whirlwind, mathematically describable in terms of components that act tangentially and perpendicularly to its motion, compelled Mary to consider the powerful result of forces that act orthogonally. In this way she understood the verse as an allegory for the inspiration that could be produced by harnessing attitudes and intellectual inclinations apparently at odds with each other. Appreciating its

25 Boole, op. cit. (11), i, 140.

26 See Boole, op. cit. (24), Chapter 22.

27 MacHale, op. cit. (6), 134-6, 196-8.

28 George died within days of falling ill with pleuro-pneumonia after walking the three miles between his home and Queen's College in a rainstorm without adequate protection from the elements. Mary recounted the events leading to George's death in 'Home-side of a scientific mind', in Boole, op. cit. (11), i, 45-8. MacHale (op. cit. (6), 240-4) elaborates on her account.

29 Boole, op. cit. (11), i, 40.

30 George Boole, letter to Augustus De Morgan dated 6 November 1862, in The Boole-De Morgan Correspondence (ed. G. C. Smith), Oxford, 1982, 102.

31 King James Version.

32 Boole, op. cit. (11), i, 77. 
significance, George encouraged her to pursue doggedly the clue she had uncovered. ${ }^{33}$ In another exchange she spoke sympathetically of the 'social excommunication ... which often follows on the publication of ... (real or supposed) heresy'. In reply, George pleaded that she should

abandon the attempt to work for or serve any other cause but the one of teaching the need of providing for those who are beginning to go on what may seem a wrong road in religion or morals, genial companionship with people of an opposite turn of mind to their own..$^{34}$

Perhaps the most significant change of heart, especially as it affected Mary, involved George's complicated feelings about Frederick Maurice. ${ }^{35}$ There is little doubt that he esteemed this charismatic and controversial cleric for, among other things, the ecumenical positions Maurice typically adopted. George fundamentally disagreed, however, with his Trinitarianism and the idolatry it fostered, yet adamantly refused to broach this subject with him out of respect for the good work he was doing. After years of encouragement Mary finally persuaded her husband to allow her to contact Maurice and express the wish that they might finally meet in order to start a mutually beneficial dialogue. George died before the letter of invitation was sent. In her first year of widowhood, Mary belatedly contacted Maurice out of a desire to understand better his position on matters with which George disagreed but upon which he refused to expound publicly. Responding to her family's straitened financial conditions following George's death, she also noted that she sought employment in an 'educational institution' ${ }^{36}$ Learning this, Maurice helped her to secure a position as a librarian at Queen's College, London, one of the first institutions of higher education for women, with which he was then affiliated. Mary supplemented her primary duties by devoting her time and energies to various ancillary activities, which included offering pastoral advice and tutorials to students. Alongside these various commitments to the institution and its students, she also maintained a theological dialogue with Maurice, one that caused her much personal distress. In particular she recounted his agitation over a biography of George that she had drafted; he also strongly advised against the publication of another manuscript she was then preparing. ${ }^{37}$ Both works were temporarily abandoned, and Mary left her employment with Queen's College in 1873, most likely by mutual consent. Her first attempt to sketch and interpret the intellectual life of

33 Boole, op. cit. (11), i, 77; ii, 795.

34 Boole, op. cit. (11), i, 44. The allegory of the dust-whirl attains even greater significance in relation to this latter exchange.

35 Mary recollected her husband's complex feelings of admiration and consternation regarding Maurice in several essays republished in her Collected Works, including 'Home-side of a scientific mind', 'Boole's philosophy' and 'Mount Carmel in London'. MacHale (op. cit. (6), 205-7) provides a good overview of this aspect of George's life.

36 Boole, op. cit. (11), i, 49. The essay cited here, 'Maurice and the National Church: a scientific experiment', primarily recounts her activities from 1865 to 1873 . Mary stated elsewhere that she felt compelled to interrogate Maurice's theological opinions in order to explain better the 'motives of [her husband's] persistent isolation' from the 'religious world' when it came time to write his biography. M. Boole, 'George Boole's philosophy', Athenaeum (1884), 238.

37 Mary claimed (op. cit. (36), 238) that she originally asked Maurice to take the lead in writing this biography. He declined her invitation, but offered his assistance. 
George was published in the (Dublin) University Magazine in 1878, appearing in four instalments under the title 'Home-side of a scientific mind'.

\section{Propagating and fulfilling a legacy: the law of pulsation}

If frustrated in her earliest literary efforts to promote George's legacy, Mary was not distracted from what she clearly considered her primary mission. Her Collected Works, including books, essays and lectures produced exclusively in the last forty years of her life, amount to over 1,500 pages of material. In these she examined mathematical, scientific, spiritual, social and political concerns. Moreover, these themes rarely appeared in isolation from each other. The project that essentially inspired all her efforts was defined by her commitment to making intellectual connections, to engaging in dialogue with those who likely harboured contrary opinions and to encouraging syntheses that would in turn inform praxis. As modern scholars have rightly noted, Mary was often maddeningly repetitious in her exposition and frequently eclectic in her choice of subject matter; nevertheless the connections she invited her audiences to make more often than not had their impetus in a consistently identifiable theme that she fashioned from elements found in the Laws of Thought.

The 'law of pulsation' constitutes the essential message Mary drew from her privileged insights into the many strands of thought that informed her husband's investigations. ${ }^{38}$ Although it is not explicitly discussed in George's treatise, this law is central to Mary's appreciation of that work and, consequently, to establishing a context for many of the intellectual interventions she would undertake in the future. She traces George's understanding of the law of pulsation to a vision he had as a young man of seventeen. In his rendering, which emerged through private conversations between husband and wife, this vision was fundamental to his efforts to recast logic as an algebraic system. Reflecting on their exchanges, Mary saw it as the moment when he first understood a great mystical secret that underpinned the law of pulsation:

The mind of man is encased in a mechanism which, besides receiving information through ... the senses, receives information also from some source, invisible and undefinable, the access to which opens whenever the mind, after a period of tension on the difference, contrast, or conflict between any elements of thought, turns to contemplate the same elements as united, or as forming parts of a unity. ${ }^{39}$

In this account Mary identified the basis for George's belief that ' $1-x$ (or not- $x$...) must belong to, and be included in, the same "Universe of Thought", as the $x$ itself'. ${ }^{40}$ Equally evident is an essential interrelationship between the unity law, which relies on this idea, and Boole's equation. The latter, algebraically formulated as $x(1-x)=0$, underscores the conscious apprehension of differences while the former, symbolically depicted by $x+(1-x)=1$, suggests that "the mind ... "functions normally towards

38 Boole, op. cit. (11), ii, 401.

39 Boole, op. cit. (11), ii, 789. Laita's careful, comparative examination of George's published work and Mary's testimonials convinces him that she was truthfully representing her husband's influences. Laita, op. cit. (7), 54-7. No one has yet offered any analysis that suggests otherwise.

40 Boole, op. cit. (11), i, 239. 
Monism" " in responding to an unconscious imperative to synthesize various pieces of information into a comprehensible whole. ${ }^{41}$ Correct thinking results from pulsations between these two mental attitudes: the 0 representative of opposition (or the act of compensation) and the 1 of unification. According to the law of pulsation articulated and cultivated by Mary, maintenance of mental elasticity simultaneously requires the regular reversal of intellectual perspective as much as it legitimates the proliferation of associations.

The doctrine of pulsation is inextricably linked with other themes that Mary incorporated into many of her works: mental hygiene, Boole's method and mathematical psychology. The first of these is typically employed in relation either to the healthy state achieved or to the regime undertaken by faithfully adhering to the practice of pulsation, which is to say by adopting Boole's method. Its significance very likely as much reflects her personal experience of growing up according to Hahnemannian principles as it does broader Victorian concerns with hygiene. At the same time, the doctrine of pulsation occupied a special place within Mary's cultivation of mathematical psychology, or what Grattan-Guinness has neatly summarized as 'a theory of mental acts'. ${ }^{42}$ According to her characterization, pulsation is related to mathematical psychology insofar as it describes a 'sequence of mental attitudes' that facilitates setting 'mental machinery to work on [a] subject as to which [one] desires [inspiration] in the same order or sequence as that followed by the mathematician'. ${ }^{43}$ Scholars have found much to discuss in considering the extent to which the Laws of Thought either can or should be read as a treatise that illuminates interrelationships between logic, mathematics and psychology. This valuable approach notwithstanding, it is clear that Mary, in her portrayal of George as a mathematical psychologist par excellence, worked from a simple premise: the act of connecting her husband's work to psychological concerns was both natural and replete with intellectual possibilities that she could develop. ${ }^{44}$

Another consistent feature of her propagation of George's legacy is its portrayed relationships with the Catholic theologian Auguste Gratry and his treatise Logique (1855). The title is somewhat misleading. As its English translator noted, the work is 'more an essay on induction and related problems, including the methods and philosophy of deduction itself as compared to induction, than a handbook for the beginning student in traditional logic'. ${ }^{45}$ Gratry's interest in addressing inductive reasoning stemmed from the fact that, unlike its deductive and syllogistic counterpart, it produces general principles from discrete experiences and observations. In attempting to explain

41 Boole, op. cit. (11), iii, 951.

42 Grattan-Guinness, op. cit. (6), 35.

43 Boole, op. cit. (11), ii, 704-5.

44 For commentary related to George Boole, psychology, and the Laws of Thought see, for example, J. Cochran, 'Aristotle's Prior Analytics and Boole's Laws of Thought', History and Philosophy of Logic (2003), 24, 261-88, 282; Grattan-Guinness, op. cit. (6); J. Richards, 'Boole and Mill: differing perspectives on logical psychologism', History and Philosophy of Logic (1980), 1, 19-36; N. Vassallo, 'Analysis versus Laws: Boole's explanatory psychologism versus his explanatory anti-psychologism', History and Philosophy of Logic (1997), 18, 151-64. Mary expressed her own opinion on this many times; see, for example, Boole, op. cit. (11), i, 75; iii, 797.

45 M. Singer, 'Introduction,' in A. Gratry, Logic (tr. H. and M. Singer), LaSalle, 1944, 7. 
the familiar yet transcendent aspect of induction, Gratry sought to correct any notions that this had to do with a 'vague process of groping'. ${ }^{46}$ Instead he argued that the process 'consists ... in searching for God and God in nature: for to seek law behind facts, unity and stability in the multiple and moving, is to look for God without knowing it'. Kepler, whose investigations Gratry highlighted, discovered unifying laws through finite observations by relying on the belief that 'the eternal ideas of God govern the world'. In the case of its use in Leibniz's development of the calculus, also prominent in Gratry's exposition, induction turns on the belief that 'the perfections of God are those of our souls, minus our limitations, and ... affirms that these infinite unlimited perfections, of which this elimination gives us some idea, are true and subsist in God '. ${ }^{47}$

Mary often linked the names of Gratry and Boole in her writing, but among her most concerted efforts are Logic Taught by Love (1890) and the Mathematical Psychology of Gratry and Boole (1897). According to her accounts, George was introduced to Logique not long after its publication and was immediately impressed by it. Certainly the mystical revelation that eventually inspired the unity law and Boole's equation, part of the inductive analysis of reasoning itself, resonated with aspects of Gratry's metaphysics. Consequently his treatise provided Mary with a context for developing themes upon which George chose not to elaborate. Moreover, Logique offered the potential to extend her mission so as to incorporate a recuperative dimension: harmonizing her husband's investigations with other currents of thought. ${ }^{48}$ For example, Gratry ended his treatise with suggestions for those who wished to foster the kind of revelatory insights associated with inductive reasoning, a key element of which is the regular observance of silence and relaxation. Indeed, he asserted that sleep, correctly prepared for, could double the time one devoted to useful work. ${ }^{49}$ In this regard Mary's expression of the law of pulsation, which speaks to the hygienic benefit of alternating periods of (synthetic and unconscious) reflection with periods of (analytic and conscious) mental tension, signals that her husband and Gratry shared common intellectual sympathies.

There were, however, important distinctions that Mary was careful to delineate. In general, her celebration of George's contributions to logic recast and extended Gratry's discussion of inductive reasoning in such a way as to deny that inspiration relies on any particular theology or religious doctrine. It was of little consequence, according to Mary,

whether the Source of Inspiration should be Jehovah, Jove, or Lord. Pan, the Unknown X, the Unity, the cosmic Force, the Great I Am, gave inspiration freely; the question was ... what sequence of mental attitudes create[s] normal receptivity, putting the human machinery into such a condition that light from the Beyond enables it to see new truth without causing it to mix that truth with delusion. ${ }^{50}$

46 A. Gratry, Logic (tr. H. and M. Singer), LaSalle, 1944, 446.

47 Gratry, op. cit. (46), 455, 448, 450.

48 Cobham, op. cit. (1), 23. As with her accounts of his relationship with Maurice, Mary often portrayed her husband in ways that variously emphasized his isolation or otherness; see for example Boole, op. cit. (11), i, 41 ; ii, 441; iii, 953.

49 Gratry, op. cit. (46), 525, 532-7.

50 Boole, op. cit. (11), ii, 704. 
Whereas one could identify Gratry's Catholicism as the impetus for his notion of prayer as a means by which finite minds make their appeal to the Infinite, Mary's articulation of the law of pulsation redirected attention by stressing the dialectical interplay between analytic (conscious) and synthetic (unconscious) phases of thought. Gratry also claimed that logic could acquire wings by accepting the relevance of faith to inductive reasoning. Mary disagreed with his assessment insofar as she felt that something more was required if logic was to be rendered 'a more powerful instrument than it had hitherto been'. She maintained that George, in moving beyond the structured syllogisms of Aristotle by encoding laws specific to mental processes within an algebraic system, deserved his share of credit for giving wings to logic - for making it 'freer and more vigorous'. ${ }^{51}$

\section{Education, pedagogy and reform}

Mary once wrote of her own efforts that 'I should be proud if I could convince a single teacher that the isolation of any mode of thought is misleading; and that no system of Logic can be valid unless it is able to focus together various rays of truth. ${ }^{52}$ While broadly employed here, the word 'teacher' indicates an important facet of the promotion and fulfilment of George's legacy: the demonstration of its significance to educational reform. Most of her writing on this topic dates from 1900. It includes both books, the most notable being Preparation of the Child for Science (1904), and articles published primarily in the Journal of Education and Parents' Review. Many of the ideas she formulated were also presented at conferences of the Parents' National Education Union. One of the most salient features of her commentary on education is that it reflects her husband's thinking informed by her personal experience. The Laws of Thought undoubtedly provided a framework, but it is also evident that she drew on her own education and involvement with tutoring students in mathematics when developing her pedagogical attitudes and suggestions. Moreover, in disseminating these, she took full strategic advantage of all aspects of her roles as a confidant to genius, parent and educator in orchestrating a presentation of George's work for an audience that would otherwise likely remain unaware of it. Were it not for her efforts at educational reform Mary might well have been consigned to historical footnotes as the rather eccentric wife of an eminent Victorian mathematician. Even so, it is surprising that while most modern commentators have rightly noted their significance, very few have explicitly acknowledged or elaborated on the various ways her ideas related to encouraging an appreciation of the laws of thought. ${ }^{53}$

51 Boole, op. cit. (11), i, 438, 439.

52 Boole, op. cit. (11), ii, 400.

53 See, for example, Creese, op. cit. (3); Howson, op. cit. (3), 170; MacHale, op. cit. (6), 258-9. There are, to some extent, exceptions in this regard. Grattan-Guinness (op. cit. (5), 54) notes that Mary 'prosecuted [George's] ideas, mainly in philosophical and educational contexts'; Laita observes (op. cit. (7), 37) that she 'called "Boole's method" a method of teaching'; Michalowicz also correctly states (op. cit. (4), 295) that her endeavours were 'directed primarily toward clarifying her husband's Laws of Thought for her lay readers'. These writers, however, all fail to explore such matters further. 
Along with other late Victorian critics, Mary disdained teaching that demanded rote memorization or study undertaken solely for the purpose of passing examinations. Moreover, she believed it was her patriotic duty to help 'improve the development of constructive imagination' in the sciences that some then felt was seriously impaired. ${ }^{\mathbf{4}}$ In response to these impulses she advocated an approach to education that, rather than demanding that students learn the 'last new theory', would best allow students to 'extract the truth from a series of impressions and statements' ${ }^{55}$ Learning, for Mary, had little to do with the passive absorption of fact; rather, the process of learning was paramount. As she once encapsulated her position: 'Education is the integration of brain and nerve action. ${ }^{56}$ To this end, Boole's method of encouraging a rhythmic pulsation between analysis and synthesis signposted the way by which education could simultaneously enhance its efficacy and reorient its goals. Interestingly, in undertaking this project, Mary performed the kind of intellectual reversal that characterizes the law of pulsation. By her accounts, George had developed mathematical insights that would extend the scope of psychological knowledge. The time had come for mathematical psychology - as she understood it - to make a contribution to teaching science and mathematics..$^{57}$

Perhaps the most prominent feature of the recommendations in Preparation of the Child for Science is the emphasis placed on developing the unconscious mind and the importance of physical manipulations to stimulate and reinforce mental processes. According to Mary, pedagogies embedded in traditional education had subordinated activities that tended to feed the unconscious imagination, considering these manifestations of idleness. Serious combat against an entrenched position could not be left to educators alone. Mary therefore spoke directly to parents about how, mindful of the expectations of a formal education, they could best provide environments in which their children's unconscious minds might thrive. The central tenet of her recommendations involves fostering what she called a 'Sabbatical rhythm in science; a clear distinction between the time when [the child] is being taught by a man and the time when he is free to investigate or experiment as he pleases. ${ }^{58}$ Elaborating on this prescription, Mary discussed the ways in which caring for animals and tending gardens could prime the unconscious for later education in the natural sciences. Further, her suggestions included domestic activities that would prepare children to appreciate formal lessons in mathematics and the physical sciences, including topics such as electricity and magnetism, hydrostatics and mechanics. ${ }^{59}$ Reform-minded teachers could reinforce the work undertaken by parents by striving to maintain a balance in their four-fold obligation as lecturers, laboratory teachers, textbook authors and cultivators

54 Cobham, op. cit. (1), 54.

55 Boole, op. cit. (11), iii, 882.

56 Mary Everest Boole, letter to Arthur Somervell dated 9 January 1905, in Cobham, op. cit. (1), 105-6.

57 At least one of Mary's devotees noted this aspect of her approach to educational reform; see Cobham, op. cit. (1), 55.

58 Boole, op. cit. (11), iii, 894-95, 895.

59 Boole, op. cit. (11), iii, 895-906. 
of an inner voice that could be called upon when the child 'retires into silence to think out the meaning of apparently conflicting evidence' ${ }^{60}$

As part of her appeal for nurturing the unconscious mind Mary paid special attention to the significant lessons learned by making mistakes. Parents who might be inclined to coddle their children or unnecessarily constrain this crucial component of the learning process failed to understand that among the intellectual hallmarks of a scientific mind 'none is more important than the habit of learning when there is no [guidance], of profiting by ... past errors, of rising on stepping stones of our mistaken selves to correct judgments'. ${ }^{61}$ While she stressed the importance of an appropriate degree of supervision, lest children inflict serious injuries upon themselves, Mary was equally adamant that they be protected in the classroom from the damage that might be done by 'directing educational care too exclusively to the conscious mind' ${ }^{62}$ In this regard, she considered Euclid's Elements the prototypical example of an inappropriate text for children who lacked the benefit of 'geometric instinct and the habit of geometric observation'. Its very danger was that it represented a masterfully distilled compendium of (geometric) knowledge; by her reasoning, such texts stifled the heuristic impulse that best engages the unconscious mind. Attempting to revise textbooks so as to disrupt hierarchical and linear narratives was not a solution for Mary. Indeed, she insisted that the 'remedy is not to substitute for Euclid some inferior and less thorough textbook, but to precede and supplement the use of textbooks by some gymnastic calculated to restore normal vitality to the paralysed natural faculty' associated with the unconscious. ${ }^{63}$ The reforming work required was not to be achieved by providing more honest historiographies of scientific and mathematical investigations nor by diluted presentations of accumulated knowledge. The changes Mary advocated were extra-textual.

The imperative to look beyond texts is intimately related to the significance Mary placed on mastering advanced concepts by way of experience with commonplace objects. The principle underpinning her commentary is, in her words, 'that actions which are artificial should be practised in connexion with ideas which are familiar; and new ideas should be learned by means of actions which are natural '.${ }^{64}$ In this scheme, regular engagements with natural objects and processes, as well as tools and simple machines, pay dividends when the child confronts concepts in the sciences. Likewise, experience with aesthetic forms and draughting tools and techniques prepare young minds for appreciating geometrical and mathematical knowledge. ${ }^{65}$ Undoubtedly, Mary's most notable personal contribution to teaching mathematical concepts in conjunction with physical activities, one probably known to many who are unaware of her connection with it, is found in her promotion of 'curve stitching' on sewing cards. By this Mary

60 Boole, op. cit. (11), iii, 889.

61 Boole, op. cit. (11), iii, 898-9, 898.

62 Boole, op. cit. (11), iii, 903.

63 Boole, op. cit. (11), iii, 904, with original emphasis.

64 Boole, op. cit. (11), iii, 902-15, 908.

65 It is in this context that Mary made one of her most often-repeated prescriptions. Specifically, she maintained that students should not be made to calculate arithmetically the greatest common divisor of two numbers until they can 'find, easily and accurately, by means of compasses, the longest interval that will repeat exactly into each of two unequal given lengths'. Boole, op. cit. (11), iii, 903. 
referred to the process of creating geometric patterns by means of holes punched into cards with thread passing amongst these according to some chosen scheme. This is her description of curve stitching:

In many of these designs lines are first drawn which represent the ribs of some natural leaf; and these are then used as co-ordinates, by means of which a leaf-outline is evoked as the envelope of a system of tangents drawn in silk ... [T] o make this exercise of any use there must be no copying from diagrams; the value of it depends on the child evoking a curve, watching it growing ... from mere obedience to a law. ${ }^{66}$

Her own childhood discovery of this form of amusement enabled Mary to provide a compelling personal account of the benefit curve stitching had when it came time to absorb and assimilate advanced concepts essential to calculus: describing tangents to curves and conceiving of curves as comprising infinitesimally short line segments. ${ }^{67}$

\section{Psychological functionalism, ethical development, gender and suffrage}

As much as they are of a piece with sentiments expressed by others then advancing the New Education in Britain, Mary's recommendations on educational reform evidence strong connections to psychological functionalism. ${ }^{68}$ It is not surprising, then, that her ideas came to the attention of William James, who, as one of its early and influential proponents, facilitated the publication of her 1902 essay on 'Suggestions for increasing ethical stability' in the Monist.$^{69}$ Partly through James, the efforts of both Booles garnered a new audience of American academics and editors. The Open Court Company, then under the leadership of the prolific and polymathic Paul Carus, who also served as editor of the Monist, republished the Laws of Thought in 1916. At that time the most recent British edition was over sixty years old. As a graduate student, the University of Chicago anthropologist Milton Singer came to appreciate Mary's writing and considered her efforts to be a contribution to logic in their own right. $^{70}$ The preface to the published proceedings of a 1927 Symposium on the

66 Boole, op. cit. (11), iii. 906. This aspect of Mary's contribution to mathematical education is examined in Innes, op. cit. (4).

67 Boole, op. cit. (11), iii, 915. MacHale (op. cit. (6), 259) suggests that curve stitching 'was invented by George Boole to amuse his daughters'. If so, it is hard to imagine that Mary failed to credit him with this.

68 Many of Mary's recommendations, especially those advocating pedagogical approaches attuned to thought processes and speaking to the essential interplay between physical activity and mental reflection, share common ground with others that emerged in the context of the New Education movement in Britain. For a thorough examination of the subject see R. J. W. Selleck, The New Education, 1870-1914, London, 1968. Although Mary cannot be considered a pioneer in her promotion of educational reforms, it is worth remembering that her contributions emphasize the importance of scientific enterprises both to defining and to effectively teaching the school curriculum. Michalowicz offers reasons that might explain a contemporaneous reluctance to acknowledge Mary's contributions to education. By way of highlighting their progressive spirit, she also considers many of Mary's suggestions on mathematical education in relation to today's curricular objectives, including cooperative learning, communication and establishing connections with other disciplines. Michalowicz, op. cit. (4), 294-8.

69 H. Henderson, Catalyst for Controversy: Paul Carus of Open Court, Carbondale, 1993, 126. Mary (op. cit. (11), iii, 976) specifically acknowledged James's assistance in preparing her essay for publication.

70 E. S. Dummer, 'Introduction', in Cobham, op. cit. (1), 10-11. Singer went on to produce the first English translation of Gratry's Logic. 
Unconscious acknowledges the relevance of both George and Mary Boole's thoughts on the subject. This further indicates that her interpretative efforts effectively communicated and developed psychological aspects of her husband's innovation. ${ }^{71}$ Indeed, the twentieth-century revival of interest in George's work ultimately owes much to Mary's contributions to psychological discourse.

As signalled by its title, 'Suggestions for increasing ethical stability' is dedicated to offering a resolution to the problem of heterogeneous and subjective nomenclature. According to Mary, 'the whole subject of ethical training is in chaos owing to words being used in an ambiguous manner, and much confusion is cleared up when the material is first algebraized and retranslated in the vernacular' ${ }^{72}$ Consequently she endeavoured to effect praxis by applying Boole's method to psychological subject matter with the aim of forming a neutral system of notation that could be applied to a variety of specific situations. The law of pulsation implicitly permeates much of her discussion of promoting the ethical quality of a life, which is described as best achieved by requiring a degree of wilful elasticity that could forestall the formation of inappropriate, fixed habits. The 'qualities of reverence, justice, etc.', she wrote, 'depend essentially on the habit of suspending action till there has been time for a mental act of conscious sympathy with facts' ${ }^{73}$ It would be difficult, however, to recover anything that might be strictly identified as the algebraization of psychological knowledge in this piece. What can be said is that she presented a scheme for systematizing 'an ethically stable nervous system' that makes use of symbolic notation representing mental states, actions and motives and suggests functional relationships between these by outlining several examples. ${ }^{74}$

Another, perhaps more notable, aspect of her treatise on ethical stability can be found in the introductory material that Mary appended to her original essay as part of its 1909 publication in book form. Its dedication indicates that this was attached to her existing essay as a response to a personal request to articulate 'in terms of Logic the reasons [she maintained] for not joining in the demand for suffrage'. The preface clearly defines both her audience and her intentions:

This book was written by a woman for women ... The task ... is to show to women that we became more logical, not while herding in gangs or competing against each other or against the male sex, but while pouring out our hearts and lives in the shelter of our own homes. ${ }^{75}$

71 E. S. Dummer, 'Introduction', in The Unconscious: A Symposium (ed. E. S. Dummer), New York, 1927, 2-8.

72 Boole, op. cit. (11), iii, 976-81, 980.

73 Boole, op. cit. (11), iii, 979, with original emphasis.

74 Boole, op. cit. (11), iii, 986-1000, 993. The following example gives a sense of her treatment. She used $A$ to denote the mental phase of conscious discrimination and $B$ for the phase in which the mind is 'dormant or passively receiving impressions' (ibid., at 986). She let $Y$ signify motives that 'act in phase $A$, but which are suspended and inefficacious in $B$ ' (ibid., at 993). With these, she asserted that $Y$ should be applied to situations in which a patient is to be 'kept awake for a certain time' owing to an overdose of drugs, for example (ibid., at 995). While Mary failed to go this far, her advice might be operationally and symbolically reduced to $Y(B)=A$. The advice she deemed appropriate to this situation is essentially tautological. Be this as it may, it is the neutralizing and generalizing formulation of the advice in terms of symbols that preoccupied Mary.

75 Boole, op. cit. (11), iii, 969. 
Her introductory comments convey sentiments indicative of thinking most closely aligned with psychological functionalism. 'The laws of logic', she wrote, 'were worked into animal organization along with dawning consciousness of the relation of the individual to environment and especially to other individuals. They are in reality the laws of self-preservation from delusions; of economy of nerve-force; of maximum efficiency with minimum waste of nervous energy' ${ }^{76}$ The law of pulsation still had a crucial role to play in her exposition; however, she now approached this from an anthropological perspective that facilitated a gendering of the laws of thought.

According to this text, general use of the word 'induction' mistakenly obscures two distinct forms of reasoning. To quote Mary,

The ... faculty of ... induction which grows up while a creature is hunting or 'prospecting' or exploring or at war is of a different quality from that which grows up while a creature is brooding over one or two small helpless things, trying to find out what makes them uneasy and how to make them comfortable. ${ }^{77}$

Mary immediately related the duality she illuminated to the distinction between inferences that give rise to general truths and those that lead to the articulation of fundamental laws such as those developed by George. ${ }^{78}$ Men had practised the first kind of induction for millennia. It gave rise to classical systems of logic upon which legal and legislative procedures had been established. In attempting to systematize the laws of thought, George and others 'were formulating the laws of a faculty [then] not recognized as having any law'. Even as she claimed the nascent 'new logic [had] ... no conventions as to conduct, no canons of procedures, no precedents', Mary assured her audience that it reflected synthetic sensibilities 'weak in men and very strong in women', those who were more adept in the second form of inductive reasoning. ${ }^{79}$

Fully cognizant of the inevitable associations that would be drawn, Mary chose to adopt labels rooted in anthropology rather than gender to distinguish between the two forms of inductive reasoning. The hunter's mode of induction is shaped by its preoccupation with contrast and tension, the mental imprint of which is encoded by Boole's equation. Alternatively, brooders structure inductive reasoning around a tendency to harmonize information, a synthetic inclination encapsulated by the unity law and encouraged by their status as non-hunters. Complete accord with the law of pulsation required the integration of these two modes of thought, albeit on a macroscopic, sociocultural level rather than the microscopic level of individual minds. To this end Mary reminded her readers that 'suffrage, the whole apparatus of voting and legislation, belongs on the whole to the male line; while silent influence is on the whole more appropriate to the female line ${ }^{80}$ Both attributes were essential to ensure social

76 Boole, op. cit. (11), iii, 970-1.

77 Boole, op. cit. (11), iii, 972.

78 Boole, op. cit. (24), 4-5.

79 Boole, op. cit. (11), iii, 973.

80 Boole, op. cit. (11), iii, 974. 
stability; 'they must take counsel together ... [for] there is nothing more sterilizing and disastrous than premature attempts at fertilization' ${ }^{81}$

As one acquainted with her later observed, the conservative position Mary adopted regarding suffrage was predicated on a belief that women are particularly well suited to bringing forth 'the new truth that is usually waiting to be born of polar opposite opinions'. ${ }^{82}$ At the same time, one can look to her work at Queen's College, London, to her commitment to tutoring women in mathematics and to her essays directed specifically at schoolgirls for evidence that her attitudes on female education, although perhaps separatist, were considerably more progressive. Consequently she can be counted among those identified in Julia Bush's work of historical reclamation, which examines late Victorian women who promoted higher educational opportunities for their sex, yet failed to embrace suffrage. Even so, Mary stands apart from many of the women Bush considers, since her opposition to suffrage was founded primarily on the significance she attached to the new logic of Boole's method and its relation to mental hygiene as opposed to appeals to, among other things, domestic stability and status, explicitly Christian sensibilities, or imperialistic imperatives. ${ }^{83}$ Moreover, she was not suggesting that embroilment in suffrage represented a direct threat to the nervous dispositions of women. Rather, anything that might encourage women to forsake the duty associated with their own special mental strength would likely compromise the health and well-being of society. Ultimately Mary amplified her agency in imploring women to fulfil their obligations to the law of pulsation by deftly combining her roles as both messenger and model practitioner.

\section{Mathematical knowledge}

The functionalist inclinations and anthropological perspectives that shape her commentary on ethical stability and the women's question also pervade much of Mary's discourse on the nature of mathematical reasoning. Central to the promulgation of her own ideas in relation to George's legacy, this theme explicitly emerges in essays already considered, specifically the Mathematical Psychology of Gratry and Boole and Preparation of the Child for Science, as well as others, including Boole's Psychology as a Factor in Education (1901), Lectures on the Logic of Arithmetic (1903) and Philosophy and Fun of Algebra (1907). In terms of explaining what mathematics is and is not, Mary consistently argued from a core belief that, although typically applied to basic concepts, suggests the true nature of the discipline. Specifically she maintained that 'arithmetic corresponds from its very origin to properties which are distinctly human, not numerical. Its processes are, from the first, anthropomorphic, not, as is commonly assumed, purely abstract' ${ }^{84}$ Adoption of this position allowed her to make several points, not the least of which involved aligning certain aspects of mathematics

81 Boole, op. cit. (11), iii, 973, with original emphasis.

82 F. Daniel, A Teacher of Brain Liberation, London, 1923, 16.

$83 \mathrm{~J}$. Bush, "'Special strengths for their own special duties": women, higher education and gender conservatism in late Victorian Britain', History of Education (2005), 34, 387-405, 388, 398, 403.

84 Boole, op. cit. (11), ii, 696. 
with other scientific enterprises. For example, essentially all scientific investigations are enhanced by the use of 'implements and methods ... of human origin', such as microscopes; in this mathematics is no different. Its processes, Mary asserted, 'are well adapted to meet the limitations of our direct faculties, and to assist us in attaining knowledge unattainable by our unaided powers'. ${ }^{85}$ By pointing out such commonality she undertook to correct a 'popular but erroneous conception of mathematics as a science differentiated from most other sciences by being purely abstract, non-human, out of line with vital processes'. Others at about this time proclaimed the kinship of mathematics with the natural sciences by drawing attention to the influence of empiricism on the production of its knowledge. Mary's commentary lays claim to a more expansive role for human agency: mathematical processes are tailored to 'meet the needs of the human mind in its effort to understand what is beyond its comprehension'. ${ }^{86}$

In exposing its more mundane roots, Mary did not mean to deny mathematics special, transcendent attributes. Although the impetus for its methods might well reflect mental limitations, its reasoning makes use of extra-logical powers. It is by appealing to inductive, non-syllogistic modes of thought that one is able to both extend calculations to contexts previously unimaginable and grasp the validity of arithmetic principles, such as the commutative property of multiplication as applied to natural numbers, by reflecting on a few computations rather than relying on repeated validations or authoritative prescriptions. This aspect of its knowledge also means that one is less likely to be led astray owing to the fallibility of common sense or hindered by hidden facts when dealing with mathematical concepts and processes. Some people may not be able to provide an immediate or correct response to a mathematical question, but this is due only to their unfamiliarity with the required techniques. Once appreciated, nothing would prevent them from arriving at the appropriate conclusion. ${ }^{87}$

Closely related to the insularity of mathematical practice from the influence of hidden facts is the 'power of self-correction which the mind possesses in relation to it'. In this regard Mary acknowledged that 'there seems to be some mysterious court of arbitration within man' that is essential to detecting and adjudicating disagreements without necessarily appealing to any external authority. ${ }^{88}$ Mary claimed that it is a myth to attribute this undeniable feature of mathematical reason to 'something in the nature of the subjects commonly treated mathematically', whether number or quantity. If this were so, then how could one account for the fact that we are as susceptible to computational errors as we are limited in our apprehension of large numbers? 'This weakness of our power of direct cognition with regard to numbers', she pointed out, 'may be partly due to lack of exercise ... [and it] might be possible to possible to strengthen it by practice. But at least it leaves ... no excuse for asserting that numbers, as such, are easier for us to [re]cognize with certainty than facts of other kinds. ${ }^{89}$ This, of course,

85 Boole, op. cit. (11), ii, 697.

86 Boole, op. cit. (11), ii, 698.

87 Boole, op. cit. (11), ii, 699-702.

88 Boole, op. cit. (11), ii, 702.

89 Boole, op. cit. (11), ii, 703. 
leaves open the question of whence the power of self-correction. Mary offered no opinion on this, but suggested that it might be philosophically sound to consider mathematics, as a developed discipline, 'a science not of number and quantity, but of conditions under which man can make his progress towards unknown Truth uniform and safe, and can preserve himself from being seriously misled by the mistakes which he is sure to make on the way'. Perhaps, she conjectured, mathematics is most appropriately considered the science of 'sane inspiration' ${ }^{90}$

Uncoupling readers' perceptions of mathematics from immediate associations with number and quantity was crucial to Mary's mission. Indeed, any hope of introducing or explaining the nature of mathematical psychology to her audience required that they appreciate the possibility, perhaps even more than the potential, of algebraically formulating the laws of thought. Consequently, she endeavoured to correct what she considered to be two fundamental myths regarding arithmetic and, by extension, algebra: first, that its subject matter is relegated to questions of number and quantity, and second, that its processes exclusively reflect laws associated with these concepts. To address the former she proffered several practices selected to expose the misapprehension that number dictated the scope of arithmetic considerations. In one example, she discussed the rules applied to computations involving negative numbers in terms of the broader conception of 'balancing ... mutually neutralizing operations', a process she felt was at least equally well appreciated in contexts defined by social interactions. ${ }^{91}$ The concept of sacrifice also played a role in arithmetic computation, for the 'whole process of numeration depends on and expresses the power and the need of the human mind to merge a group of its ideal units of one stage into a single higher unit' ${ }^{92}$ The five examples she provided all highlight social or psychological processes. These therefore simultaneously serve to dispel the other identified myth. ${ }^{93}$ By offering these she was also able to reinforce her underlying belief that mathematics reflects dynamics indelibly marked by human actions and emotions.

In his efforts to mathematize the laws of correct reasoning George anticipated, to a considerable degree, foundational questions that would occupy many logicians, mathematicians and philosophers for years. Simply posed, these ask, 'what constitutes mathematics?' and 'how does one account for the certainty of its knowledge?'94 Psychologism, the belief that psychological experiences provide a framework for explaining the laws of logic and/or mathematics, has often been the focus of discussions of George's philosophical temperament. ${ }^{95}$ Nevertheless, his Laws of Thought contains relatively few passages that explicitly address the nature of mathematical knowledge.

90 Boole, op. cit. (11), ii, 703-4, 704.

91 Boole, op. cit. (11), ii, 791-3, 791.

92 Boole, op. cit. (11), ii, 793.

93 Mary's other examples (op. cit. (11), ii, 791) include 'the determining of a unit of thought; the concept of negation; ... [and] reasoning by analogic operation'. All of these contribute to practical suggestions for introducing schoolchildren to arithmetic topics in Lectures on the Logic of Arithmetic (in Boole, op. cit. (11), iii, 803-74).

94 Indeed, Grattan-Guinness discusses George Boole's work in a chapter that serves as a prelude to late Victorian explorations of mathematical foundations. See Grattan-Guinness, op. cit. (5), Chapter 2.

95 See, for example, Vassallo, op. cit. (44); Richards, op. cit. (44). 
He certainly reminded readers that such knowledge is not conceptually bound to notions of number. Further, he ended his exposition with the claim that mathematics, while a fundamental component of it, did not exhaust the full scope of human knowledge. ${ }^{96}$ In developing her discourses on mathematics, it is not to be suggested that Mary wielded any influence either directly or indirectly on foundational debates. It is, however, undeniable that she was aware of them and willing to present somewhat maverick, psychologistic views to general audiences that would likely have had little exposure to such ideas. Furthermore, through this engagement, she once again fulfilled a function intimately related to Boole's method by providing an ideological inversion of George's sentiments: while he maintained that mathematics is an essential aspect of human knowledge, Mary asserted that humanistic imperatives formed the essential core of mathematical knowledge. In this she anticipated aspects of the constructivist epistemological models later espoused by theorists such as Jean Piaget. ${ }^{97}$

\section{Scientific enterprises, practices and authority}

Mary made strategic use of her mission to disseminate and interpret the Laws of Thought as a way of giving voice to opinions she held regarding scientific enterprises other than mathematics. While various works contain evidence of her thinking, addresses she delivered in the 1890s are of particular interest. Her most obvious target at the time was the practice of vivisection in biological research and medical training, but the concerns she addressed related to all sciences. The views she espoused undoubtedly reached a smaller audience than some of her published works. Nevertheless they provide the clearest insights into the way Mary formulated her attitudes regarding the professionalization and specialization of science in the context of the law of pulsation. Further, her commentary suggests that she developed her own explanation to account for the fact that George's system, either on its own or in any broader context, was largely ignored by his peers. ${ }^{98}$ In rendering and presenting her views on these matters she critically challenged as much as effectively negotiated parameters then typically associated with scientific authority.

Before it offers specific objections to vivisection, Mary's critique begins by acknowledging the impotency of arguments framed around an outdated misconception that moral objections could significantly alter the course or pace of scientific progress. ${ }^{\mathbf{9}}$ She believed that those inclined to prioritize moral righteousness above intellectual

96 Boole, op. cit. (24), 12, 422-4.

97 Drawing upon Yvette Solomon's survey of his theories, such attitudes anticipate Piaget to the extent they suggest that 'logico-mathematical thought is the result, not of direct experience of the world, but our actions in the world'. Further, Mary's opinion that mathematical knowledge is inherent in actions and not embedded in numbers themselves, or the objects under consideration, is also consistent with Piaget's view. Yvette Solomon, The Practice of Mathematics, London, 1989, 21.

98 Grattan-Guinness (op. cit. (5), 55) notes this fact, but does not conjecture upon reasons that might account for it. That much of Mary's writing on vivisection was produced within the span of a few years is exemplary of her inclination to 'drop some movement suddenly after having shown great sympathy with its promoters'. E. M. Cobham, 'Introduction', in Boole, op. cit. (11), 25.

99 Boole, op. cit. (11), ii, 530-2. 
progress also risked underestimating the useful knowledge that biological and medical research might generate. ${ }^{100}$ Abandoning spiritual rhetoric, she chose instead to frame her objections in terms that scientists claimed as an essential part of their remit: the pursuit of 'intellectual truth'. Specifically, Mary was able to position herself within this discourse by arguing that anyone who professed such aims must be obliged to learn the laws of thought and practise the doctrine of pulsation. That scientists had largely failed in this duty was evident in the problem of vivisection, which she described as the 'eruption ... of a disease ... infecting all of the intellectual and educational life of the world' ${ }^{101}$ Mary's argument ultimately defines the disease pervading science by symptoms directly related to the improper employment of the law of pulsation, or indeed ignorance of its primacy to logical thought.

Vivisection in biological and medical research provided Mary with a particularly rich context in which to address the risks inherent in the pervasive disregard of good mental hygiene in the sciences. She maintained that its experimental emphasis on dissection and differentiation made excessive demands on the analytic phase of pulsation to the detriment of its synthetic complement. Such predominance suggested that balance must be regained. 'We might safely give any man leave to do as much vivisection as he cared to do', she wrote,

on condition of ... reversing his mental action at the close of each day or week; because on that condition he would remain a sane agent, and not become the prey of those illogical hallucinations which come of distorting mental powers by exercising them in violation of the law of their action. ${ }^{102}$

This prescription, however, was not meant to be limited to the sphere of a scientist's particular subject matter, where synthetic reassessment after analytic reduction was taken as a methodological requirement. ${ }^{103}$ Indeed, she intended that the act of pulsation go further in attempting to bridge professional practices with those outside any special study. To this end vivisectionists should regularly attempt to put themselves or family members in place of their subjects as a means of fostering the mental elasticity that sanity required.

Mary highlighted other anxieties associated with the continued violations of the law of pulsation in biology and medicine. For example, she was especially concerned that educational programmes structured around vivisection would produce new generations of researchers who would accept the practice as an absolute necessity for research. She was willing to concede that some might profess a preference for vivisection as part of their research. But to claim it was the only means possible for attaining useful knowledge indicated both an unsoundness of mind and an ignorance of intellectual history. ${ }^{104}$ Furthermore, she worried that a dependence on vivisection in medical schools would only reinforce weaknesses in students with less-developed synthetic faculties, arguing

100 Boole, op. cit. (11), ii, 554, 557.

101 Boole, op. cit. (11), ii, 531.

102 Boole, op. cit. (11), ii, 539.

103 Boole, op. cit. (11), ii, 558.

104 Boole, op. cit. (11), ii, 536-7; ii, 554-5. 
that such deficiencies require less, not more, attention being paid to observational abilities. ${ }^{105}$ What, she mused, of the student who 'cannot learn by synthesis, from some facts - if he must see all the facts with bodily eyes, how can he diagnose in the case of a living patient ? ${ }^{\mathbf{1 0 6}}$ Ultimately, her concerns extended to all medical practitioners who, while typically ignorant of regimes of sound mental hygiene themselves, were allowed to commit others to institutions and asylums. ${ }^{107}$

An additional aspect of the general scientific malaise that troubled Mary is notable inasmuch as it shifts focus from particular elements of George's contributions to logic. Instead it draws attention to her efforts at expanding the contexts - whether metaphysical, historical or disciplinary - in which they might be appreciated. A central problem with science, she asserted, manifests itself in

confusion between love of truth and lust for the mere sensation of personal discovery; a frantic craving for such modes of investigation as can be completed within the lifetime of the individual, and contempt for those methods by which a great truth is given to the public, after having been discovered by the unselfish co-operation of several students. ${ }^{108}$

According to the narrative developed throughout her Collected Works, the Laws of Thought at once represented a hallmark in a lifelong quest and occupied a special place in an intellectual lineage that could claim affinity with, among other things, Jewish religious tradition, the theology of Auguste Gratry and the spiritual influences of her father. Additionally, Mary often referred to the support and encouragement George received through his long correspondence with Augustus De Morgan, whom she portrayed as a faithful collaborator and someone appreciative of the full extent of her husband's undertaking. ${ }^{109}$ She was, however, critical of those who later turned their attention to his work, most notably William Stanley Jevons and John Venn. While acknowledging their improvements to cumbersome notation, she particularly chided Jevons for focusing his considerable talents on specific applications of George's innovation, yet failing to apprehend, and thereby disregarding, the true scope of its power and potential. ${ }^{110}$ Indeed, she once likened the reception of the Laws of Thought among the British intelligentsia to the magnanimous gift of a steam hammer being exclusively employed for the menial task of cracking nuts. ${ }^{111}$ The pervasiveness of such blinkered and specialized mindsets not only impeded the recognition she felt her husband was due; according to Mary, these also corrupted the true spirit of scientific investigations. In making this point she sought to (re-)establish her authority in promoting George's ideas.

Mary's commentary on vivisection merges lifelong engagements with health and medical practitioners, which can be traced to the Hahnemannian influences on

105 Boole, op. cit. (11), ii, 551-2.

106 Boole, op. cit. (11), ii, 552, with original emphasis.

107 Boole, op. cit. (11), ii, 527.

108 Boole, op. cit. (11), ii, 531, with original emphasis.

109 Boole, op. cit. (11), iii, 952.

110 Boole, op. cit. (11), ii, 438; ii, 795 ; iii, 962.

111 Boole, op. cit. (11), iii, 955. 
her childhood, with her later preoccupation with interpreting the laws of thought. Consequently, she undoubtedly considered herself well suited to formulating a critique that attempts to elevate discourses on biological research, in particular, and scientific enterprises, in general, above mere moralistic sermonizing. Indeed, Mary intended to raise the tenor of her contribution by harnessing the new logic encapsulated by the law of pulsation. Certainly hers was an antagonistic voice from outside an increasingly distinctive and persistently male scientific community, but it encouraged harmonizing attitudes even as it highlighted differences of opinion. As such, the Law of Pulsation served to legitimate as much as define her intercession. Another interesting aspect of Mary's lectures on vivisection is her observation regarding the self-gratifying pleasure she claimed scientists took in their particular researches. Indeed, the lustful and sensual terms employed when describing this symptom of the scientific malaise she sought to expose foreshadow a Foucauldian analysis of the medicalization of sexuality. ${ }^{112}$ Finally, apropos of Kathryn Neeley's scholarship, if the notion of a distinctly illuminated female mind provides a meaningful analytic framework for historicizing Victorian women who cultivated scientific enterprises, then Mary certainly represents a worthy subject insofar as she herself maintained that women's mental faculties are particularly attuned to accord rather than conflict. Nevertheless, her comments on selfishness in science illustrate one of the many paradoxes that typically complicate any such gendered perspective, for there she used the intellectual (masculine) platform of the laws of thought to expose and denounce emotional (feminine) motives that undermined scientific research.

\section{Conclusion}

In addition to the topics discussed heretofore, Mary's efforts at propagating and fulfilling her husband's legacy extended to commentary on Judaism, Eastern mysticism, spiritualistic mediumship, imperialism and economics. This is an undeniably diverse array of topics. Yet her intellectual mission of framing and disseminating as much as acting in accordance with the law of pulsation was a commitment to fostering new ideas and influencing praxis through the proliferation of associations. It is clear that she also envisioned her continuing engagement with George's contributions to logic as transcending the role of a mere biographer; hers are collaborative narratives. She writes as one who knowingly and tactically occupied a privileged position from which she developed her own ideas by contextualizing her husband's innovative work, embedding it within a rich intellectual history, demonstrating its relevance to a variety of discourses, and articulating its import to audiences outside of purely academic circles.

The constancy of her dedication to the law of pulsation represents the most obvious point of ideological commonality amongst what can otherwise seem a disparate set of attitudes and engagements. It gave shape to her progressive opinions on the nurture of the unconscious mind, on the role of psychology in educational reform and on

112 M. Foucault, History of Sexuality, vol. 1 (tr. R. Hurley), London, 1990, 44-5, 48. 
the significance of human activity to mathematical reasoning as much as it effectively underpinned her conservative position on suffrage. Further, in commenting on the social and intellectual obligations of women, Mary amplified her agency by practising what she preached. She notably exercised the special, complementary mental strength she attributed to women by her gendered presentation of the law of pulsation in several other contexts. This is, for example, evident in the critique she mounted against vivisection and the male preserve of science, in which she suggested that such practices must harmonize their efforts with the laws of correct reasoning. Ultimately, identifying some of the themes, motives and strategies around which she organized her many efforts to promote the laws of thought enables us to reconsider her interventions - like those undertaken by other Victorian women who sought to cultivate scientific enterprises - within a contextual framework expansive enough to include purposeful responses to cultural realities, expectations and possibilities.

Mary often declared that her husband George gave wings to logic. Yet it is she who, in her own ways, devoted herself to promulgating ideas that spoke to their continued appreciation and vitality. 